\title{
PERAWATAN METODE KANGURU PADA BAYI BERAT BADAN LAHIR RENDAH
}

\author{
https://doi.org/10.33024/jkpm.v4i6.4515
}

Ike Pudji Wahyuningsih*1, Febi Ratnasari², lis Kuraesin ${ }^{1}$, Kristina Natalya Rewo ${ }^{1}$, Nida Lila ${ }^{1}$, Ifolisah ${ }^{1}$, Hesti Setiawati ${ }^{1}$, Ni Nyoman Yeni Puspitasari ${ }^{1}$, Neneng Hasanah ${ }^{1}$, Endang Sri Wahyuni ${ }^{1}$, Neneng Rohmawati ${ }^{1}$, Dwi Septiningsih ${ }^{1}$, Dwi Ariyani ${ }^{1}$

1,2STIKES Yatsi Tangerang

Disubmit: 14 Juni 2021 Diterima: 18 Juni 2021 Diterbitkan: 01 Desember 2021

Email Korespondensi: ikepudji26@gmail.com

\begin{abstract}
ABSTRAK
Perawatan metode kanguru adalah perawatan untuk bayi berat lahir rendah dengan melakukan kontak langsung antara kulit bayi dengan kulit ibu. Perawatan metode kangguru adalah cara yang sederhana untuk merawat bayi baru lahir dimana ibu menggunakan suhu tubuhnya untuk menghangatkan bayi. Manfaat Perawatan Metode Kanguru : menghangatkan bayi dan menstabilkan tanda vital bayi karena berat badan bayi premature cenderung rendah, jaringan lemak di dalam tubuhnya juga cenderung lebih tipis. Meningkatkan durasi tidur mekanisme yang terjadi pada saat kontak kulit dengan kulit ibu dan bayi dapat meningkatkan hormone kortisol pada bayi yang berdampak pada kualitas tidur bayi meningkat. Mengurangi tangisan dan kalori yang terbuang dari bayi. Meningkatkan berat badan bayi dan perkembangan otak bayi premature cenderung memiliki berat badan lahir rendah dan terkadang sulit mencapai berat badan ideal. Metode ini dapat membuat tidur bayi lebih nyenyak, sehingga energinya bisa tersalurkan untuk memperbaiki fungsi tubuh dan membangun jaringan tubuh dengan lebih baik. Dengan demikian berat badannya pun bisa naik lebih cepat. Meningkatkan hubungan emosional bayi dan ibu KMC meningkatkan bounding ibu dan bayi serta merupakan intervensi terapeutik untuk meningkatkan kedekatan ibu, mempromosi perilaku alami untuk stimulasi pertumbuhan dan perkembangan. Mempemudah pemberian ASI posisi metode kanguru memudahkan bayi dapat menyusu pada ibunya sekaligus memicu ASI agar lebih mudah keluar. Beberapa riset menunjukan bahwa metode ini juga baik untuk mengatasi masalah ASI kurang. Ibu dan keluarga merasa lebih puas karena berperan dalam perawatan bayi selama di RS dan di rumah. Tujuan penelitian ini adalah mengetahui bagaimana gambaran pengetahuan masyarakat tentang perawatan metode kanguru pada bayi berat badan lahir rendah. Penelitian ini menggunakan metode presentasi ppowerpoint dan video. Hasil dari presentasi dan demonstrasi yang dilakukan adalah sebanyak $20.8 \%$ pengetahuan masyarakat meningkat setelah pemaparan materi.
\end{abstract}

Kata kunci: BBLR, Perawatan Metode Kanguru 


\begin{abstract}
Kangaroo method care is a treatment for low birth weight babies by making direct contact between the baby's skin and the mother's skin. Kangaroo care is a simple way of caring for a newborn in which the mother uses her body temperature to warm the baby. Benefits of Kangaroo Treatment Method: warms the baby and stabilizes the baby's vital signs because premature babies tend to be low in weight, fat tissue in their bodies also tends to be thinner. Increasing the duration of sleep, the mechanism that occurs during skin contact with the skin of the mother and baby can increase the hormone cortisol in the baby which has an impact on the quality of the baby's sleep. Reduces crying and wasted calories from babies. Increasing baby weight and brain development Premature babies tend to have low birth weight and sometimes find it difficult to reach the ideal weight. This method can make the baby sleep more soundly, so that the energy can be channeled to improve body functions and build body tissues better. This way, you can gain weight more quickly. Improving the emotional connection of the baby and the mother KMC increases the bonding between the mother and the baby and is a therapeutic intervention to increase the closeness of the mother, promoting natural behavior to stimulate growth and development. Facilitate breastfeeding The position of the kangaroo method makes it easier for babies to suckle from their mothers while triggering breast milk to come out more easily. Some research shows that this method is also good for dealing with the problem of insufficient breast milk. Mothers and families feel more satisfied because they play a role in caring for the baby while in the hospital and at home. The purpose of this study was to find out how the description of public knowledge about kangaroo care methods in low birth weight infants. This research uses ppowerpoint and video presentation methods. The results of the presentations and demonstrations carried out were as much as $20.8 \%$ public knowledge increased after the presentation of the material.
\end{abstract}

Keywords: LBW, Kangaroo Method Care

\title{
1. PENDAHULUAN
}

Setiap tahun di dunia diperkirakan lahir sekitar 20 juta bayi berat lahir rendah (BBLR). Kelahiran BBLR sebagian disebabkan oleh lahir sebelum waktunya (premature), dan sebagian karena mengalami gangguan pertumbuhan selama masih dalam kandungan. Di Negara berkembang BBLR banyak dikaitkan dengan tingkat kemiskinan. 2,3 BBLR merupakan penyumbang utama angka kematian pada neonates. BBLR merupakan factor resiko yang mempunyai kontribusi terhadap kematian dan kelahiran bayi khususnya pada masa perinatal. Dampak kelahiran BBLR berpengaruh terhadap kualitas generasi mendatang, ditandai dengan lambatnya pertumbuhan dan perkembangan anak dan akan berpengaruh penurunan kecerdasan (Solehati, 2018).

Berdasarkan human development report 2014 BBLR masih merupakan masalah kesehatan di Negara-negara berkembang. Total kelahiran di dunia 15.5\% kelahiran BBLR. Kelahiran dengan BBLR dua kali lebih banyak di Negara berkembang disbanding dengan Negara maju, dengan sebanyak $72 \%$ terjadi di Asia (Herawati, 2020).

Beberapa upaya pencegahan serta pengendalian BBLR bisa dilakukan dengan cara, memberikan pendidikan kesehatan kepada ibu hamil, 
melakukan pengawasan dan pemantauan dan melakukan upaya pencegahan hipotermia pada bayi serta membantu mencapai pertumbuhan normal (Novitasari, 2020).

BBLR adalah penyebab utama kematian bayi di Indonesia yaitu $29 \%$ diikuti asfiksia $27 \%$, tetanus neonatorum $10 \%$, masalah gangguan pemberian ASI $9 \%$. Perawatan pada bayi berat badan lahir rendah sangat kompleks. Bayi perlu di rawat di incubator, biaya perawatan yang cukup tinggi dan membutuhkan tenaga kesehatan yang berpengalaman. Jumlah incubator di rumah sakit sangat terbatas disbanding dengan jumlah BBLR yang dirawat. Sebuah metode yang sederhana yang bermanfaat meningkatkan kelangsungan hidup bayi BBLR adalah perawatan metode kangguru (PMK) (Nur, 2020).

Menurut sulistyorini (2012) salah satu cara untuk mengurangi kesakitan dan kematian BBLR adalah dengan perawatan metode kangguru atau perawatan bayi lekat. Metode ini sangat bermanfaat untuk merawat bayi berat badan lahir rendah baik di rumah sakit maupun di rumah (Herawati, 2020).

Menurut penelitian, alasan dan motivasi ibu melakukan PMK diantaranya, dengan PMK bayi akan mendapatkan kehangatan sehingga tidak perlu incubator terus-menerus. Dengan dilakukan PMK, bayi akan meningkat berat badannya, selain itu untuk mempertahankan keselamatan dan kelangsungan hidup bayinya (Wahyuni, 2013).

Perawatan metode kanguru mampu meningkatkan berat badan bayi, peningkatan suhu tubuh, pernafasan bayi lebih stabil. Karena bayi dalam kondisi yang nyaman, posisi istirahat yang tenang sehingga bayi tidur dalam waktu yang lama dan tidak gelisah (Sumiyati, Wahyuningsih, \& Lusiana, 2020).

Pelaksanaan PMK yang baik bermanfaat dalam peningkatan produksi ASI sesuai dengan penelitian yang dilakukan oleh yeslina 2018. Selain itu PMK juga meningkatkan kepercayaan diri ibu dan keluarga dalam merawat bayi dengan BBLR (Hutabarat \& Aryaneta, 2019).

Factor yang paling dominan dalam pelaksanaan perawatan metode kanguru adalah sikap ibu, sebagaimana ditunjukan oleh penelitian tri budi lestari 2013, sikap ibu yang baik dan kuat dalam pelaksanaan PMK menjadi factor keberhasilan dilakukannya PMK (Lestari, 2013).

Menurut penelitian yang dilakukan Nurlaila dan Eka Riyanti 2020, bahwa sebagian besar ibu merasa lebih nyaman saat menggunakan gendongan kanguru standar. Karena gendaongan standar memiliki kantong yang menopang badan bayi sehingga tidak khawatir bayi jatuh dan bentuknya kotak di depan serta tebal sehingga bayi dapat bersandar di gendongan (Nurlaila, 2020).

Sedangkan menurut penelitian yang dilakukan Sholihatul dkk 2019, tidak ada perbedaan secara bermakna persepsi ibu saat melakukan PMK dengan tiga jenis gendongan PMK yaitu model kantong, thari dan kain panjang. Tetapi mayoritas ibu memilih gendongan jenis kantong (Amaliya, 2019).

\section{MASALAH}

Pentingnya perawatan pada bayi berat badan lahir rendah yang terjangkau dan sangat mudah dilakukan, agar bayi dengan berat badan lahir rendah dapat tumbuh dan berkembang dengan baik, membuat kelompok melakukan kegiatan penyuluhan kesehatan tentang perawatan metode kanguru. Kegiatan ini dilakukan di Jl.Aria Santika No.40A Rt 005/Rw 011, Margasari Kecamatan Karawaci Kota Tangerang 15114. 


\section{METODE}

\section{a. Tahap Persiapan}

Tahap ini dimulai dengan pembuatan proposal kegiatan, pembuatan materi penyuluhan dan pembuatan link dengan media Zoom.

b. Tahap Pelaksanaan

Pelaksanaan dilakukan ketika semua peserta acara sudah masuk di link Zoom. Acara dibuka oleh MC dan dilakukan sambutan dan tujuan kegiatan oleh ketua panitia. Kemudian dilakukan pemaparan materi melalui presentasi powerpoint kemudian dilajutkan dengan pemutaran video cara melakukan perawatan metode kanguru. Setelah selesai dilakukan sesi Tanya jawab dan evaluasi post test.

\section{c. Evaluasi}

1) Struktur

Kegiatan diikuti oleh 115 peserta yang terdiri dari berbagai macam kalangan. Diantaranya $81,7 \%$ mahasiswa, $7 \%$ ibu rumah tangga dan $11,3 \%$ ibu pekerja.

2) Proses

Pelaksanaan kegiatan dimulai pukul 09.00-11.00 wib. Melalui link Zoom.

\section{HASIL DAN PEMBAHASAN}

Hasil dari kegiatan dapat dilihat dari table dibawah ini. Pengukuran hasil pengetahuan berdasarkan Arikunto 2006.

Tabel 4.1 Peserta

\begin{tabular}{cccc}
\hline NO & KATEGORI & JUMLAH & PERSENTASI \\
& & & \\
\hline 1 & MAHASISWA & 94 ORANG & $81,7 \%$ \\
$\mathbf{2}$ & IBU RUMAH TANGGA & 8 ORANG & $8 \%$ \\
$\mathbf{3}$ & IBU PEKERJA & 13 ORANG & $11,3 \%$ \\
& JUMLAH & 115 ORANG & $100 \%$ \\
\hline
\end{tabular}

Tabel 4.2 Hasil Pre Test

\begin{tabular}{cccc}
\hline NO & KATEGORI & JUMLAH & PERSENTASI \\
& & & \\
\hline 1 & BAIK & 79 ORANG & $68,7 \%$ \\
2 & CUKUP & 20 ORANG & $17,4 \%$ \\
3 & RENDAH & 16 ORANG & $13,9 \%$ \\
& JUMLAH & 115 ORANG & $100 \%$ \\
\hline
\end{tabular}

Tabel 4.3 Hasil Post Test

\begin{tabular}{llll}
\hline NO & KATEGORI JUMLAH & PERSENTASI
\end{tabular}

\begin{tabular}{cccc}
\hline 1 & BAIK & 103 ORANG & $89,6 \%$ \\
2 & CUKUP & 7 ORANG & $6,1 \%$ \\
3 & RENDAH & 5 ORANG & $4,3 \%$ \\
& JUMLAH & 115 ORANG & $100 \%$ \\
\hline
\end{tabular}


Tahun [JURNAL KREATIVITAS PENGABDIAN KEPADA MASYARAKAT (PKM), P-ISSN:
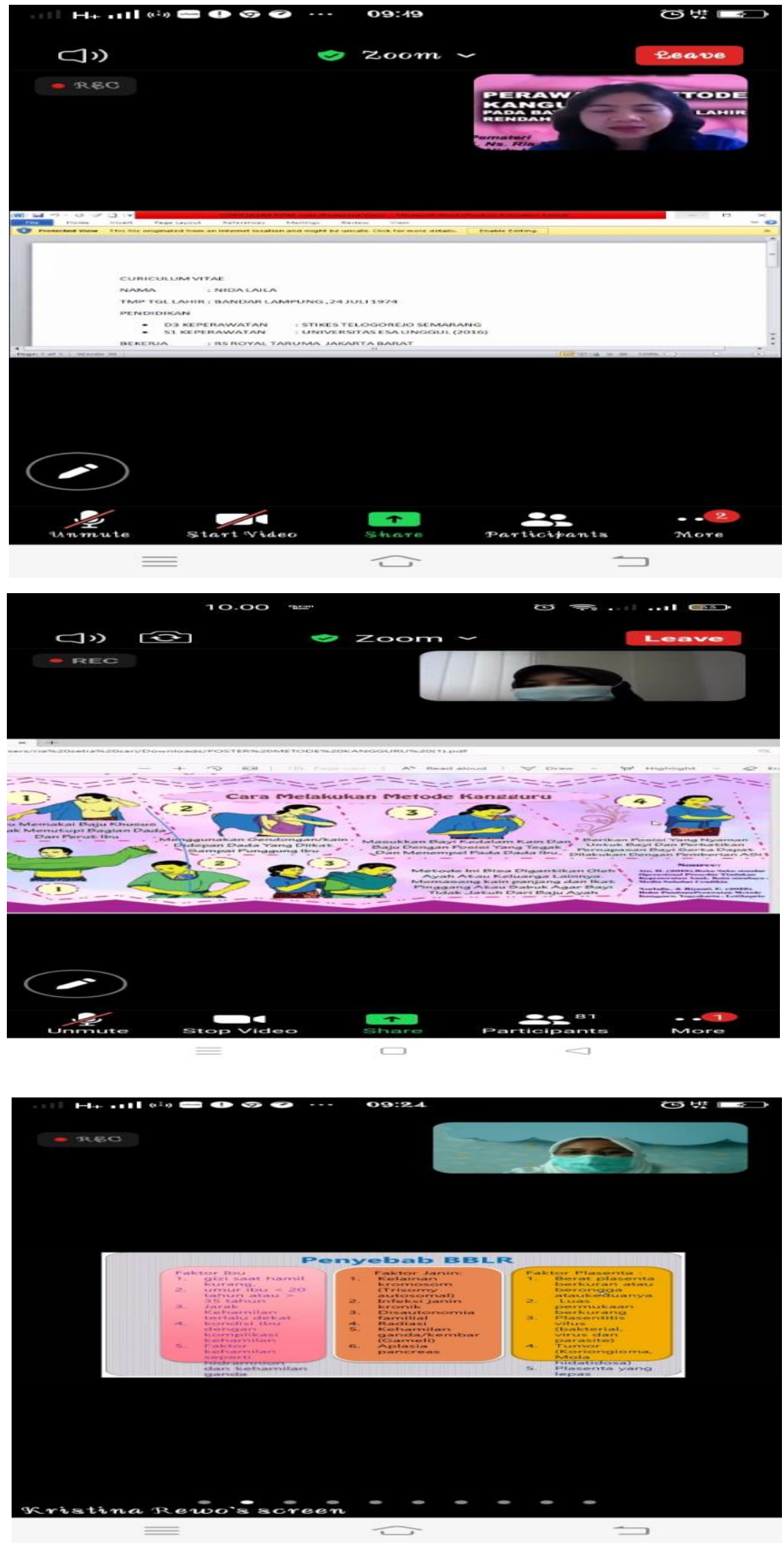

Gambar Pelaksanaan Kegiatan 


\section{KESIMPULAN}

Kegiatan ini dilakukan melalui zoom meeting di rumah masing-masing. Jumlah peserta yang hadir sebanyak 115 peserta dari berbagai kalangan. Kegiatan dimulai dengan memberika pre tes kepada peserta, setelah itu dilakukan pemaparan materi oleh pemateri mengenai BBLR dan perawatan metode kanguru. Setelah pemaparan selesai dilakukan pemutaran video cara penggunaan gendongan dalam perawatan kanguru, kemudian dilakukan post tes kepada peserta webinar.

\section{DAFTAR PUSTAKA}

Amaliya, S. Y. R. (2019). Persepsi Ibu Terhadap Berbagai Model Gendongan Perawatan Metoda Kanguru (PMK): Pilot Studi. Jurnal Keperawatan Malang, 33-41.

Herawati, I. (2020). Efek Perawatan Metode Kangguru Terhadap Kenaikan Berat Badan Pada Bayi Berat Lahir Rendah. Jurnal Kebidanan Dan Kesehatan Nasional, 1-66.

Hutabarat, Y., \& Aryaneta, Y. (2019). Pengaruh Perawatan Metode Kangguru Terhadap Produksi Asi Pada ibu Dan Kepercayaan Diri Ibu Primipara Dalam Merawat Bayi Di Wilayah Kerja Puskesmas Batu Aji Kota Batam Tahun 2018. Jurnal Kebidanan, 09(02), 33-40.

Lestari, T. B. (2013). Faktor Pelaksanaan Kangaroo Mother Care Pada Byi BBLR.

Novitasari, A. M. S. (2020). Pencegahan dan Pengendalian BBLR di Indonesia: Systematic Review. Indonesian Journal of Health Development, 175-182.

Nur, S. A. (2020). Perawatan Metode Kanguru Pada Bayi Berat Badan Lahir Rendah. Jurnal Abdimas Saintika, 4-6.

Nurlaila, E. R. (2020). Kebutuhan Gendongan dalam Perawatan Metode Kanguru Pada Bayi Berat Lahir Rendah. Jurnal Kebidanan Dan Keperawatan Aisyah, 260-273.

Solehati, T. (2018). Kangaroo Mother Care Pada Bayi Berat Lahir Rendah: Sistematik Review. Jurnal Keperawatan Masyarakat, 83-96.

Sumiyati, Wahyuningsih, T., \& Lusiana, A. (2020). Perawatan Metode Kanguru Pada Bayi Berat Lahir Rendah. Jurnal Sains Kebidanan, 2(2), 26-29.

Wahyuni, S. D. P. (2013). Pengalaman Ibu Dalam Melakukan Perawatan Metode Kanguru. 183-195. 